\title{
Projected Warming and Occurrence of Meteorological Droughts-Insights from the Coasts of South India
}

\author{
Dhanya Praveen*, A. Ramachandran \\ Centre for Climate Change and Adaptation Research, Anna University, Chennai, India \\ Email: ${ }^{*}$ hhanyapraveen.cc@gmail.com
}

Received 26 March 2015; accepted 7 May 2015; published 11 May 2015

Copyright (C) 2015 by authors and Scientific Research Publishing Inc.

This work is licensed under the Creative Commons Attribution International License (CC BY). http://creativecommons.org/licenses/by/4.0/

(c) (i) Open Access

\section{Abstract}

The latest development in the climate change forecast, using regional climate models, made it possible to provide more detailed information on the future changes in the climatic variables in the face of global warming. The PRECIS, UK Met office Hadley Centre's Regional Climate Model is being used in simulating the future climate corresponding to the IPCC-SRES A1B emission scenario for the period 2040-2070 with reference to the base line year 1970-2000 for coastal region of Thiruvallur, South India. The results indicated a significant increase in the mean maximum temperature, mean minimum temperature and a slight decrease in the precipitation over the study area. The outcomes of the IMD method of Percent Deviation analysis show that the Thiruvallur has witnessed moderate to mild droughts during the period 1970 to 2011. Moderate drought years were mainly 1974, 1980, 1982 and 1999 with $-35.78 \%,-30.09 \%,-30.54 \%,-27.30 \%$ rainfall deviations respectively. SPI-12 is also employed to analyze the occurrence and severity of drought events in the past. The analysis revealed that the year 1974 with SPI value $\mathbf{- 2 . 0 5}$ was the extremely severe drought year on record during the period 1970-2011. The years $1982(-1.7), 1980(-1.67), 1999$ $(-1.48)$ were severe dry years. Pearson's correlation analysis proved that both the outputs have significant positive correlation $\left(0.05\right.$ level) with $R^{2}$ value of 0.992 . It is necessary to develop early warning systems and apt drought preparedness strategies to cope with this natural hazard.

\section{Keywords}

Global Warming, Drought, Standardised Precipitation Index, Climate Change, Regional Climate Modelling, Impacts

\footnotetext{
${ }^{*}$ Corresponding author.
}

How to cite this paper: Praveen, D. and Ramachandran, A. (2015) Projected Warming and Occurrence of Meteorological Droughts-Insights from the Coasts of South India. American Journal of Climate Change, 4, 173-179. 


\section{Introduction}

Regional climate models provide us projections of future climate with better spatial and temporal variability [1]. Climate change is evolving as one of the leading environmental tribulations facing the modern world. According to Inter Governmental Panel on Climate Change (IPCC) global temperature will increase in the range of $1.8^{\circ} \mathrm{C}$ to $4^{\circ} \mathrm{C}$ with an overall average increase of $2.8^{\circ} \mathrm{C}$ in temperature under various representation concentration pathways [2]. The recent advancement global climate simulation models helped us to better understand the future climate change based on different emission scenarios [3]. These high resolution future climatic scenarios have been used in different parts of the world for climate change impact assessment [4]-[7]. Regional variations in the direction and magnitude of these changes will be the driving force for changes in the drought conditions.

Drought is an extended period when a region notes a deficiency in its water supply, whether surface or underground water [8]. Drought varies with regard to the time of occurrence, duration, intensity and extent of the area affected [9]. There is a strong apprehension over the impacts of future climate change on the creating drought situations as it is a slow moving natural hazard. Meteorological drought is a situation when there is a significant decrease in precipitation from the normal over an area. It is very essential to evaluate the occurrence of droughts in an area order to formulate various management strategies. So this study attempts to project future climate change and understand the drought prevalence in the study area using long term time series analysis of rainfall data.

\section{Material and Methods}

\subsection{Study Area}

The study area lies in the northeast part of the state of Tamil Nadu in south India between latitude $12^{\circ} 15^{\prime}$ and $13^{\circ} 15^{\prime}$ and longitude between $79^{\circ} 15^{\prime}$ and $80^{\circ} 20^{\prime}$. It lies adjacent to the Chennai metropolitan city. It is the second most populous district of Tamil Nadu. This region can be placed under the tropical semi arid to dry sub humid climate, as the coastal stretch comes under the latter and interior parts comes under the former category. The district is mainly dependent on the monsoon rains This area receives rain under the influence of both southwest and northeast monsoons. Most of the rain obtained is in the northeast monsoon due to cyclonic storms caused by the depressions in Bay of Bengal, chiefly during October-November and December months. The rainfall is highly erratic. Failure of monsoon leads to distress conditions. Agriculture is the main source of livelihood. The major crops cultivated are paddy, groundnut, sugarcane and finger millets.

\subsection{Climate Projections}

The PRECIS, a Regional Climate Model (RCM) was run at a regional level with a resolution of $25 \mathrm{~km} \times 25 \mathrm{~km}$ and boundary data of HADCM3Q with A1B scenario from 1970 to 2100 continuously. A1 story line and scenario family expects a future world of very rapid economic growth, global population that peaks in mid century and declines thereafter with a rapid introduction of new and more efficient technologies. This scenario is further divided based on the alternative directions of technological change in the energy use. In A1B, there is a balance across all energy sources. Climate data (precipitation, Temperature) for the Tiruvallur district are utilized in this study.

\subsection{Assessment of Past Drought}

Meteorological drought is a situation when there is a significant decrease in precipitation from the normal over an area. In this paper the percentage deviation of rainfall (PDR/Di) method The Indian Meteorological Department (IMD) and Standardized Precipitation Index (SPI) developed by McKeee [10] are used in this paper.

IMD method is used as it is simpler and widely used, one which will give a preliminary idea about the drought condition of an area. In this method, drought is assessed on the basis of percentage deviation of rainfall from the long-term annual mean rainfall.

If the range of Di is more than 0 it is called as No Drought (M0), if it is between 0 to -25 it is classified as mild drought(M1), and if it is between the -25 to -50 it is known as moderate drought (M2) and if the departure is above $-50 \%$ it comes under severe drought (M3).

SPI is computed by considering the precipitation anomaly with respect to the mean value for a given time 
scale, divided by its standard deviation. The precipitation is not a normal distribution, at least for time-scales less than one year. Therefore, the variable is adjusted so that the SPI is a Gaussian distribution with zero mean and unit variance.

A so adjusted index allows to compare values related to different regions. Moreover, because the SPI is normalized, wet and dry climates can be monitored in the same way. The index calculation is based on the following expressions (Table 1 ).

Pearson's Correlation Analysis has also been used to evaluate the relationship between the output values derived through IMD method and SPI method.

\section{Results and Discussion}

\subsection{Projections of Future Climate Change for Thiruvallur District}

Future projections for maximum temperature for the period 2040-2070 shows a maximum increase of $2.5^{\circ} \mathrm{C}$ and projections of mean minimum temperature over the period from 2040-2070 shows a maximum increase of $2.6^{\circ} \mathrm{C}$ for Tiruvallur district. The observed mean maximum temperature during the base line period 1970-2000 was $34.35^{\circ} \mathrm{C}$. The mean minimum temperature recorded in this district during the base line period was $23.81^{\circ} \mathrm{C}$. The maximum increase in the maximum temperature was over the western and interior parts of the district comprising the taluks Tiruttani, Tiruvallur and Gummudipundi. Parts of the coastal Taluks are showing an increase of $2.2^{\circ} \mathrm{C}$ to $2.4^{\circ} \mathrm{C}$ which is lesser compared to the western and northeastern parts of the district (Figure 2). The intensity in the increase in mean minimum temperature is more in the western and north western parts compared to the coastal stretch this could be attributed to the differencial heating of land near to the sea and cooling effects of sea breeze in the coastal tracks. The increase in the minimum temperature is in the range from $2.4^{\circ} \mathrm{C}$ and $2.7^{\circ} \mathrm{C}$ (Figure 1).

The projections for 2040-2070 indicate a general decrease in precipitation of about $12 \%-15 \%$ from the base line period1970-2000 based on the emission scenario A1B (Figure 2). Reduction in precipitation with reference to the base line period indicates that the agriculture may have to undergo many potential challenges. Analysis of the model output reveals that plausible warming scenarios coupled with reduction in the precipitation may create moisture stress conditions during the mid $21^{\text {st }}$ century.

\subsection{Assessment of Past Drought}

\section{A. IMD method of PDR}

Assessing the characteristics of drought in an area would help in understanding the prevailing situations. As it is recurring climatic extreme event, analysis of the frequency and extent to which it appears also requires special attention. The analysis revealed that Kancheepuram experienced Moderate drought years in 1974, 1980, 1982, 1999 with $\mathbf{- 3 5 . 7 8 \%}, \mathbf{- 3 0 . 0 9 \%}, \mathbf{- 3 0 . 5 4 \%}, \mathbf{- 2 7 . 3 0 \%}$ deviation from the normal rainfall respectively. The percentage deviation of rainfall for the years 1973,1991 and 2002 were $-20.35 \%,-20.39 \%,(-22.2 \%)$ respectively. The results of the analysis reveal that the mild drought years were 1970, 1971, 1986, 1987,1989,1990, 1994, 1995, 1998, 2000, 2001, 2004, 2006 and 2009 etc. (Figure 3).

\begin{tabular}{|c|c|}
\hline SPI values & Classes \\
\hline$>2$ & Extremely wet \\
\hline 1.5 to 1.99 & Very wet \\
\hline 1.0 to 1.49 & Moderately wet \\
\hline-0.99 to 0.99 & Near normal \\
\hline-1 to -1.49 & Moderately dry \\
\hline-1.5 to -1.99 & Severely dry \\
\hline$<-2$ & Extremely dry \\
\hline
\end{tabular}



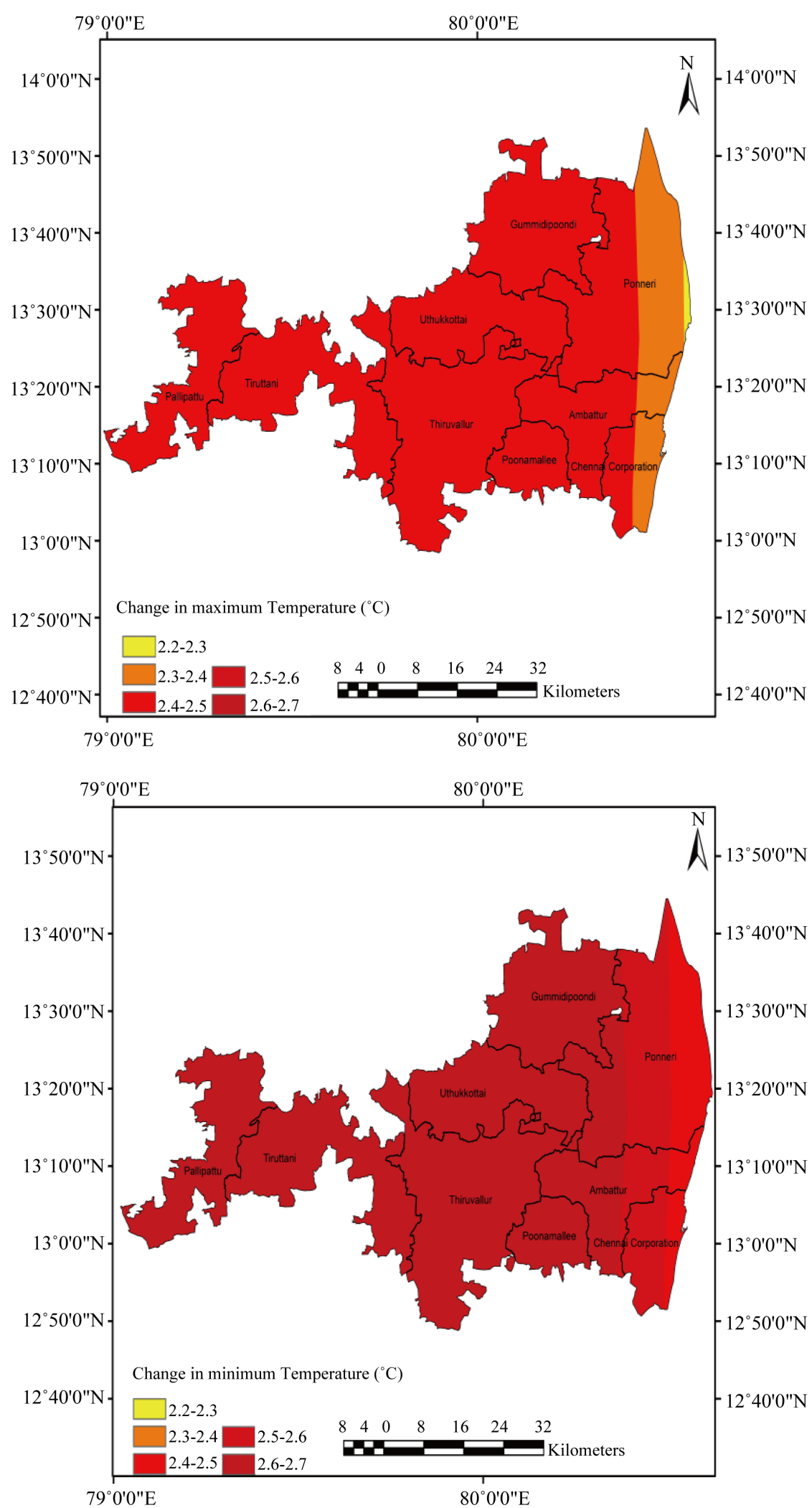

Figure 1. Changes in mean maximum temperature and mean minimum temperature for the period 2040-2070 over thiruvallur district, Tamil Nadu. 


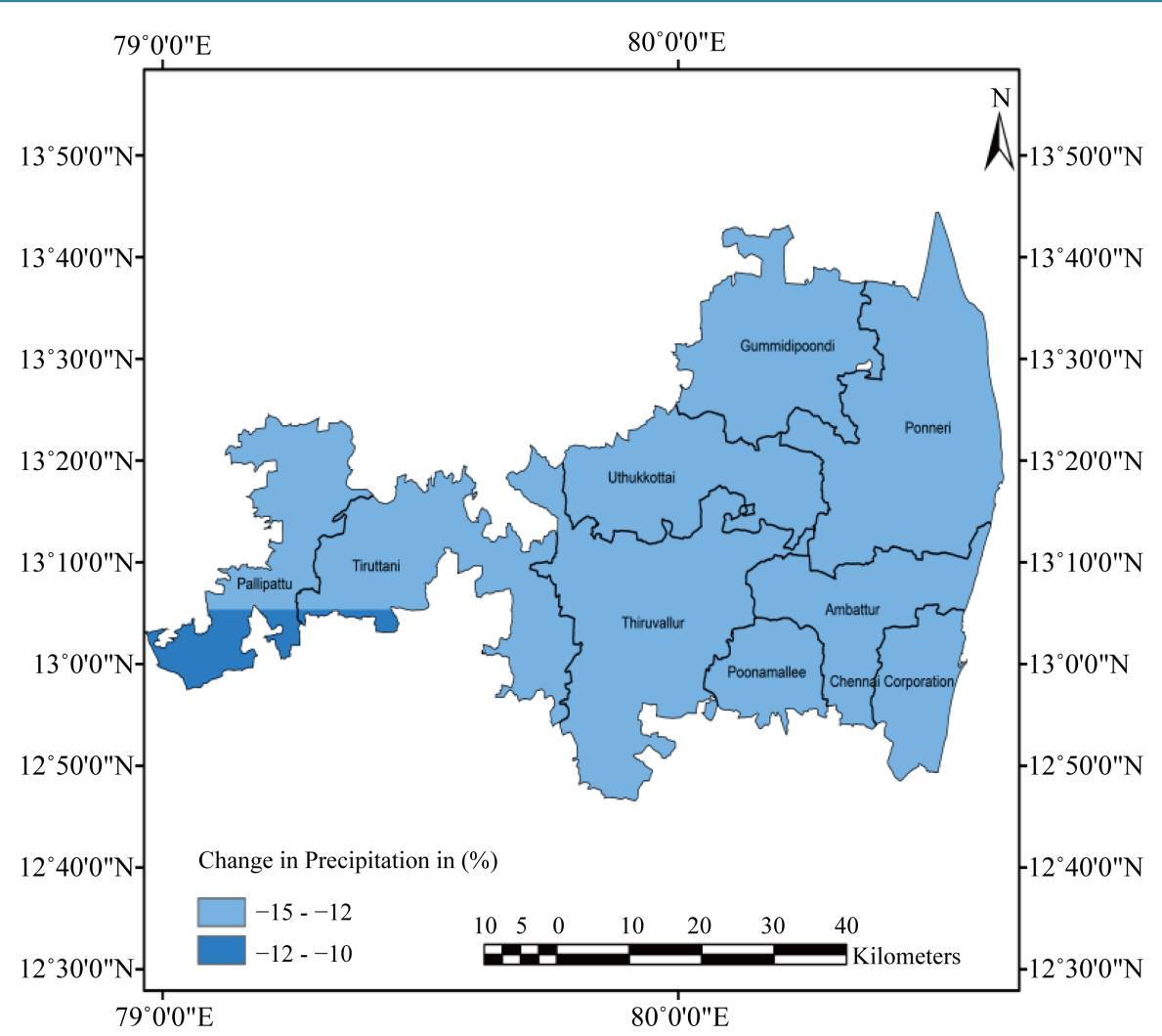

Figure 2. Percentage Change in the precipitation for the period 2040-2070 over Thiruvallur District with reference to the base line period 1970-2000.

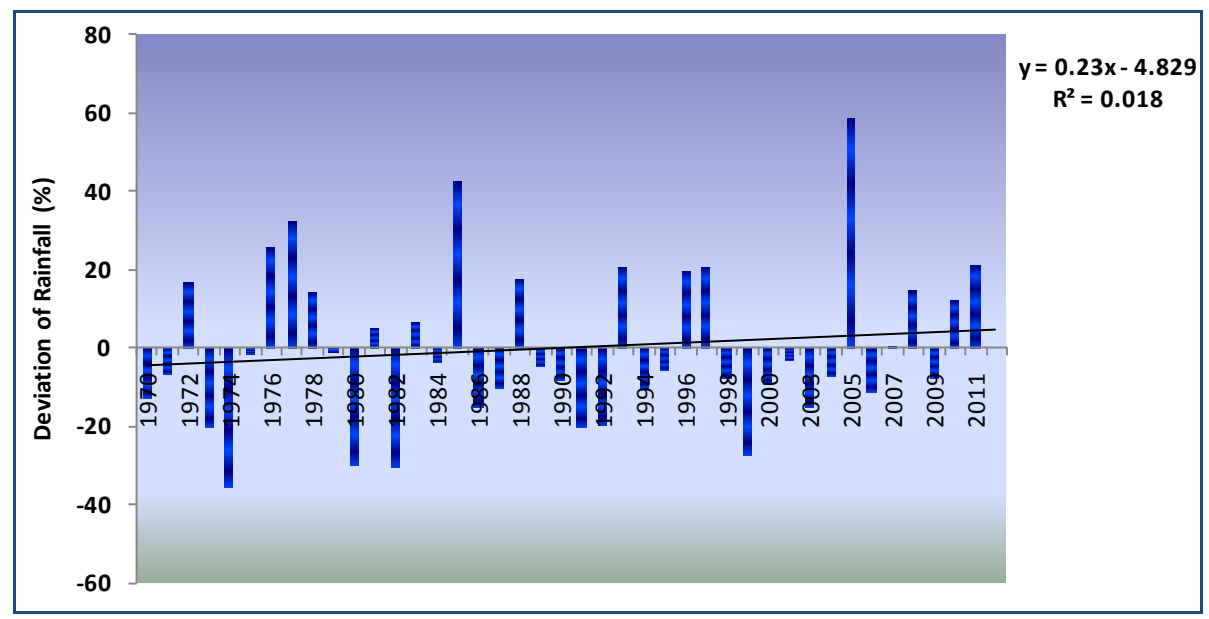

Figure 3. Percentage deviation of rainfall from 1970-2011.

B. SPI-12 is employed to analyze the occurance and severety of drought events over this district in the past. The analysis revealed that the year 1974 with SPI value -2.05 was the extremely severe drought year on record during the period 1970-2011. The years $1982(-1.7), 1980(-1.67), 1999(-1.48)$ were severe dry years and the years $1991(-1.05), 1992(-1.01), 1973(-1)$ comes under the moderately dry catogary (Figure 4).

C. The comparison of pairs of drought index values of both SPI and PDR is done using Pearson correlation Coefficient. The results from the Correlation Analysis shows that both the methods give similar outputs. The scatter plots (Figure 5) of the output variables from both the methods shows a significant positive correlation (0.05 level) with $\mathrm{R}^{2}$ value of 0.992 . 


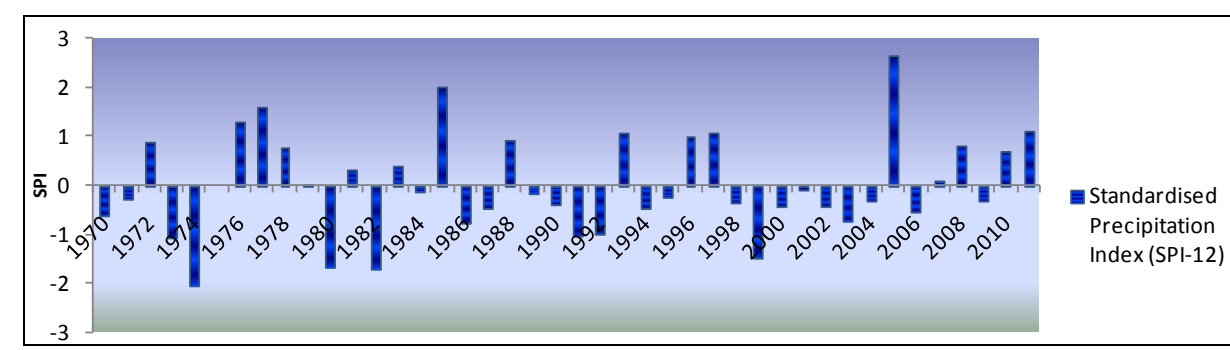

Figure 4. Standardised precipitation index (SPI-12) from 1970-2011.

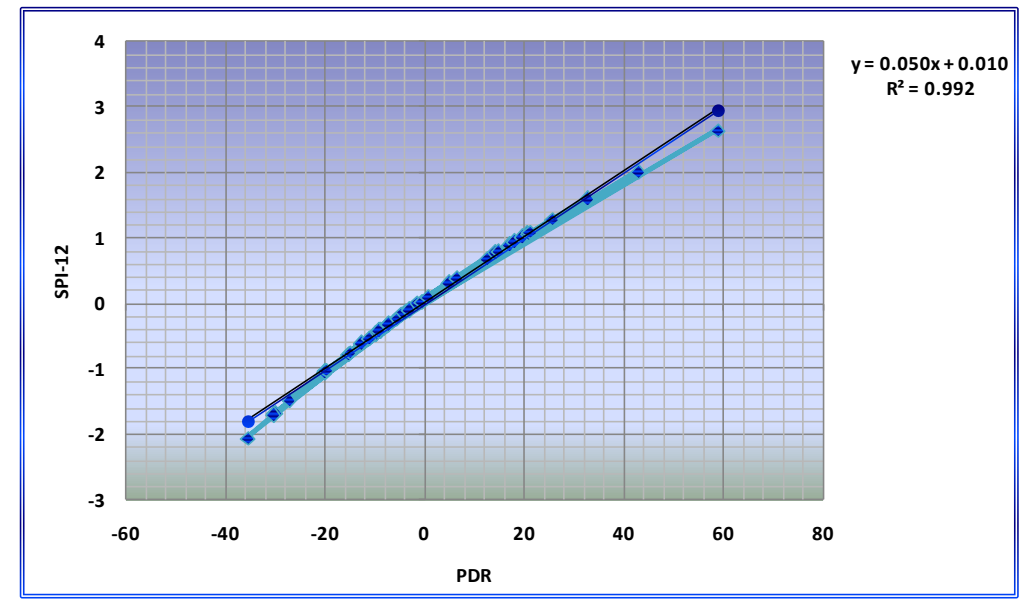

Figure 5. Scatterplot showing the relationship between SPI \& PDR.

The meteorological drought analysis shows that there were 4 severe dry years during the study period.

Dynamic and erratic nature of climate accelerates droughts which is a complex phenomena having multiple effects on various sectors. Nathan [11] has reported that the drought of 1980 had destroyed the groundnut crop over one lakh $(100,000)$ hectares in the districts of Chengalpet areas. The frequency of occurrence of droughts in Tamil Nadu is once in three years [12]. The anticipated warming stand as yet another major challenge for warrants assessments on the existing situations with respect to impacts and immediate responses in offering apt solutions for drought hit areas [13]. The consequences of drought range from water supply shortages and crop losses to famine and human abandonment of geographic regions. Drought is more recurrent during June-September. Its severity and extent during this season is believed to be more dependent on rainfall aberrations.

It is widely accepted that climate change may exacerbate far reaching consequences on coastal ecosystems and pose developmental challenges in each sector [14]. The key findings of Chaturvedi et al. [15], provides multimodel and multi-scenario temperature projections for India under RCP 4.5 and RCP 6.0 which represent the moderate scenarios, reinstates a projected increase in mean temperature ranges from $2.9^{\circ} \mathrm{C}$ to $3.3^{\circ} \mathrm{C}$. The night time temperature alone may increase by $2^{\circ} \mathrm{C}$ in RCP4.5 and $3.4^{\circ} \mathrm{C}$ in RCP8.5. This may worsen the already existing water scarcity in various parts of India in general and especially in the study area, which is already a semi arid track. The plight of the farmer has always been a matter of concern in almost all the states in India due to various reasons, and is only further reinforced by the recurrence of the droughts that cause untold hardships. Identification, monitoring and characterization of droughts at sub district and even at village level have been the topic of much research at the national and international levels. Even though IMD, National Remote sensing Centre of Indian space research Centers and disaster management cells at state level are carrying out real time drought monitoring and evaluations in India, but long term rainfall assessment for finding out the drought situations at district level needs special notice at least in future.

\section{Conclusion}

This study was an attempt to project climate change in the mid century period using RCM and analyze the historical drought in during the period 1970-2011 using two types of drought indices namely SPI and PDR. Pro- 
jected changes in the climate especially the increase in maximum temperature and minimum temperature and reduction in precipitation amount would seriously impact the ecosystems in general and current cropping patterns in the study area in particular. Drought imparts a crawling long term setbacks to the various sectors like agriculture, water and socioeconomic sectors. Both the indices captured all the major dry periods manifested in the history in the study area with high significant positive correlation. So both the methods are in agreement with each other so could be taken as a useful indicators for drought evaluation. With this knowledge on climate change, the projected increase in warming, may intensity the duration, and frequency of extreme climatic events especially drought and dry spells in future. Appropriate measures need to be adopted for managing agricultural water use in order to minimize the future impacts to a great extent.

\section{Acknowledgements}

The first author thankfully acknowledges the Anna Centenary Research Fellowship Fund, under the Department of Civil Engineering, Anna University, Chennai for providing the financial support for this research work. We are thankful to the modeling team at the Centre for Climate Change and Adaptation Research for the data support.

\section{References}

[1] Wang, B., Kang, I.-S. and Li, J.-Y. (2004) Ensemble Simulation of Asian-Australian Monsoon Variability by II AGCMs. Journal of Climate, 17, 803-818.

[2] Zhang, Y., Xu, Y.L., Dong, W.J., Cao, L.J. and Sparrow, M. (2006) A Future Climate Scenario of Regional Changes in Extreme Climate Events over China Using PRECIS Climate Model. Geophysical Research Letters. http://dx.doi.org/10.1029/2006GL027229

[3] Islam, S., Rehman, N., Sheikh, M.M. (2009) Future Change in the Frequency of Warm and Cold Spells over Pakistan Simulated by the PRECIS Regional Climate Model. Climate Change, 94, 35-45.

[4] Krishna Kumar, K., Patwardhan, S.K., Kulkarni, A., Kamala, K., Rao, K.K. and Jones, R. (2011) Simulated Projections for Summer Monsoon Climate over India by a High-Resolution Regional Climate Model (PRECIS). Current Science, 101, 312-326.

[5] Rupa Kumar, K. (2006) High Resolution Climate Change Scenarios for India for the 21st Century. Current Science, 90, 334-345.

[6] Bonacci, O. (1993) Hydrological Identification of Drought. Hydrological Processes, 7, 249-262. http://dx.doi.org/10.1002/hyp.3360070303

[7] Pandey, R.P. and Ramasastri, K.S. (2002) Incidence of Droughts in Different Climatic Regions. Hydrological Sciences Journal, 47, 31-40. http://dx.doi.org/10.1080/02626660209493020

[8] McKee, T.B., Doesken, N.J. and Kleist, J. (1993) Relationship of Drought Frequency and Duration to Time Scale. 8th Conference on Applied Climatology, 17-22 January 1993, Anaheim, 179-184.

[9] Nathan, K.K. (1995) Assessment of droughts in Tamil Nadu. http://digitalcommons.unl.edu/cgi/viewcontent.cgi?article=1057\&context=droughtnetnews

[10] Roy, P.S., Joshi, P.C., Murthy, C.S. and Kishtawal C.M. (2006) Geoinformatics for Drought Assessment. In: Samra, J.S., Singh, G. and Dagar, J.C., Eds., Drought Management Strategies in India, ICAR, New Delhi, 23-60.

[11] Meehl, G.A., Stocker, T.F., Collins, W.D., Friedlingstein, P., Gaye, A.T., Gregory, J.M., Kitoh, A., Knutti, R., Murphy, J.M., Noda, A., Raper, S.C.B., Watterson, I.G., Weaver, A.J. and Zhao, Z.-C. (2007) Global Climate Projections. In: Solomon, S., Qin, D., Manning, M., Chen, Z., Marquis, M., Averyt, K.B., Tignor, M. and Miller, H.L., Eds., Climate Change 2007: The Physical Science Basis. Contribution of Working Group I to the Fourth Assessment Report of the Intergovernmental Panel on Climate Change, Cambridge University Press, Cambridge, United Kingdom and New York.

[12] Drought Management. http://indiagovernance.gov.in/files/drought_management.pdf

[13] IPCC (2007) The Regional Impact of Climate Change: An Assessment of Vulnerability-A Special Report of Working Group II of the Intergovernmental Panel on Climate Change. Climate Change 2007: The Physical Science BasisSummary for Policymakers.

[14] IPCC (2013) Terrestrial and Inland Water Systems. Final Draft, Chapter 4 [Online]. https://www.ipcc.ch/pdf/assessment-report/ar5/wg2/drafts/fd/WGIIAR5-Chap4_FGDall.pdf

[15] Chaturvedi, R.K., Joshi, J., Jayaraman, M., Bala, G. and Ravindranath, N.H. (2012) Multi Model Climate Change Projections for India under Representative Concentration Pathways. Current Science, 103, 1-12. 